\title{
Characterization of Nicotianamine Isolated from Soybeans
}

\author{
Kohei Kuroda $^{1}$, Kohji Ishihara ${ }^{1} \&$ Noriyoshi Masuoka ${ }^{1}$ \\ ${ }^{1}$ Department of Life Science, Graduate School of Science, Okayama University of Science, Kita-ku, Okayama, \\ Japan \\ Correspondence: Noriyoshi Masuoka, Department of Life Science, Okayama University of Science, 1-1 \\ Ridai-cho, Kita-ku, Okayama 700-0005, Japan. Tel: 81-86-256-9593. E-mail: masuokan@dls.ous.ac.jp
}

Received: January 8, 2013 Accepted: February 11, 2011 Online Published: February 27, 2013

doi:10.5539/jfr.v2n2p49 URL: http://dx.doi.org/10.5539/jfr.v2n2p49

\begin{abstract}
Angiotensin I-converting enzyme (ACE) [EC 3.4.15.1] plays one of important roles to control the arterial blood pressure. Inhibitory activity of the enzyme has been reportedly detected in plant foods.

We examined the activity in plant foods and isolated an ACE inhibitor in soybeans. The structure was identified as nicotianamine, $N$-[N-(3-amino-3carboxypropyl)-3-amino-3-carboxypropyl]-azetidine-2-carboxylic acid. The contents in several soybean foods were estimated using an amino acid analyzer. The chelation capacity of nicotianamine with metals was examined using a mass spectrometer.

Soybean foods contained considerable amounts of nicotianamine but fermentation caused a decrease in the nicotianamine content. The (1:1) adduct formation of nicotianamine with metals was directly observed in the mass spectra.
\end{abstract}

Keywords: nicotianamine, angiotensin-1 converting enzyme inhibitor, metal chelation

\section{Introduction}

Hypertension is one of the major risk factors for cardiovascular disease and is estimated to affect one-third of the population in the world. The arterial blood pressure is controlled with the rennin-angiotensin-aldosterone system. In them, angiotensin I-converting enzyme (ACE) plays one of important roles to control the arterial blood pressure, and mineral balance. The enzyme catalyzes the hydrolysis of angiotensin I to angiotensin II, a potent vasoconstrictor (Guerrero et al., 2012). Angiotensin II also stimulates the release of aldosterone from the cortex in adrenal gland to control the mineral balance. As the inhibitors for ACE, captopril and other drugs, are used for treatment of hypertension, the inhibition activity in several foods was examined to find the inhibitors in foods. From them we chose soybeans and isolated the inhibitor. The compound was an amino acid, and the structure was identified as nicotianamine (NA) (Takahashi et al., 2003) (Figure 1).<smiles>N[14C](=O)[14CH]=[14CH][14CH2]N[14C]([14CH2][14CH2][14C](=O)O)C(=O)O</smiles>

Figure 1. Nicotianamine: $N$-[N-(3-amino-3carboxypropyl)-3-amino-3-carboxypropyl]-azetidine-2-carboxylic acid

\section{Materials and Methods}

\subsection{Materials}

Plant foods, soybeans (Glycine max, harvested in October in Hokkaido, Japan) and related products, were purchased from a local store in Okayama, Japan. Hippuryl-L-histdiyl-L-leucine, $N$-[3-(2-Furyl) acryloyl]-Leu-Gly-Pro-Ala, ACE, lipoxygenase [EC 1.13.11.12] and collagenase [EC 3.4.23.3] were obtained from Sigma-Aldrich Co. (St. Louis, MO, USA). The TLC plate (silica gel $60 \mathrm{~F}_{254}$ ) was obtained from the Merck Co. (Frankfurter, Germany). Trifluoroacetic acid and other chemicals were purchased from the Wako Pure 
Chemical Industries, Ltd. (Osaka, Japan).

\subsection{Preparation of Plant Food Samples for ACE Inhibition Assay}

Each food type $(1.0 \mathrm{~g})$ was homogenized three-times with $50 \%$ aqueous ethanol solution $(5.0 \mathrm{~mL})$ for $5 \mathrm{~min}$. Then, the mixture was centrifuged at $3000 \mathrm{rpm}$ for $10 \mathrm{~min}$, and the supernatants were collected. The mixture was evaporated, and the residue (sample) was stored in a freezer $\left(-20^{\circ} \mathrm{C}\right)$ until use.

\subsection{ACE Inhibition Assay}

The inhibitory activity was assayed by a modified method (Cushman \& Cheung, 1971). The sample was dissolved with $1.0 \mathrm{~mL}$ of $200 \mathrm{mM}$ borate buffer (pH8.3). The sample solution $20 \mu \mathrm{L}$ was added to $50 \mu \mathrm{L}$ reaction mixture containing ACE $\left(0.2\right.$ units) and preincubated at $37^{\circ} \mathrm{C}$ for $5 \mathrm{~min}$. Then, $7.7 \mathrm{mM}$ hippuryl-L-histdiyl-L-leucine $130 \mu \mathrm{L}$ was added and reacted for $30 \mathrm{~min}$. The reaction was stopped by the addition of $10 \%$ trifluoroacetic acid $30 \mu \mathrm{L}$, and the mixture was analyzed by HPLC at $228 \mathrm{~nm}$.

\subsection{Isolation of a Compound from Soybeans Having ACE Inhibition Activity}

Soybeans $(500 \mathrm{~g})$ were homogenized with mixer for $5 \mathrm{~min}$. The mixture was extracted three-times with hot water $\left(95^{\circ} \mathrm{C}, 2.5 \mathrm{~L}\right)$ for $30 \mathrm{~min}$, and the extract was washed three-times with ethyl acetate and then $n$-butanol. The water layer was applied to a cation-exchange column (Amberlite IR-120B, $\mathrm{H}^{+}$-form, $\Phi 4.0 \times 40 \mathrm{~cm}$ ). The column was eluted with water and then $0.5 \mathrm{M}$ aqueous ammonia solution. The ammonia fraction was collected and evaporated, and the residue was applied to an anion-exchange column (Dowex $1 \times 4$, acetate-form, $\Phi 2.0 \times 34 \mathrm{~cm}$ ). The column was eluted with water and then $0.1 \mathrm{M}$ acetic acid. The fractions containing high inhibitory activity were collected and then applied to a gel filtration column (Sephadex LH-20, $\Phi 2.0 \times 27 \mathrm{~cm}$ ). The column was eluted with water. The high activity fractions were collected and purified with TLC (silica gel, $0.2 \times 20 \times 20 \mathrm{~cm}$; ammonia: $n$-propanol $=1: 1)$. One hundred sixty eight $\mathrm{mg}($ Yield $=0.034 \%)$ of a compound were isolated, and the structure was identified as NA using ESI-MS (electrospray ionization mass spectrometry) of AccuTOF CS (JEOL Ltd., Tokyo) and 400Mz ${ }^{1}$ HNMR (JEOL Ltd., Tokyo).

\subsection{Determination of NA Contents in Soybean Food}

Soymilk, okara (soybean curd lees), kinu curd (tofu), momen curd (tofu), natto (fermented soybeans), soy sauce (fermented), and soybean paste (fermented), were directly purchased from the store. Each soybean food $(1.0 \mathrm{~g})$ was immediately homogenized and extracted three-times with hot water. The extract was washed with organic solvents, and the water layer was purified using an Amberlite IR-120B column. The ammonia fraction was evaporated. The residue was dissolved with $0.02 \mathrm{M} \mathrm{HCl}$. The solution $(20 \mu \mathrm{L})$ was analyzed by an amino acid analyzer L-8800 (Hitachi Co. Ltd., Tokyo).

\subsection{Inhibition of Lipoxygenase with NA}

To $0.1 \mathrm{M}$ sodium borate buffer (pH 9.0) $2.97 \mathrm{~mL}$ at $25^{\circ} \mathrm{C}, 10 \mu \mathrm{L}$ of $0.52 \mu \mathrm{M}$ lipoxygenase and $5 \mu \mathrm{L}$ of $0.5-100$ $\mathrm{mM}$ aqueous NA solution were added. The reaction was started by the addition of $15 \mu \mathrm{L}$ of $3.0 \mathrm{mM}$ linoleic acid and the mixture was reacted at $25^{\circ} \mathrm{C}$ for $5 \mathrm{~min}$, with the absorbance at $234 \mathrm{~nm}$ continuously recorded for $5 \mathrm{~min}$ (Rickert \& Klinman, 1999).

\subsection{Inhibition of Collagenase with $N A$}

This assay was performed with a modified method (Thring, Hili \& Naughton, 2009) using microcuvettes (50 $\mu \mathrm{L})$. A mixture of $22.5 \mu \mathrm{L}$ of $50 \mathrm{mM}$ Tricine buffer ( $\mathrm{pH} 7.5$ ) containing $400 \mathrm{mM} \mathrm{NaCl}, 10 \mathrm{mM} \mathrm{CaCl}_{2}, 25.0 \mu \mathrm{L}$ of $1.875-120 \mathrm{mM}$ NA solution and $12.5 \mu \mathrm{L}$ of collagenase (Chostridum histolytium, $8.0 \mathrm{unit} / \mathrm{mL}$ ) was put into microcuvette. The mixture was preincubated at $25^{\circ} \mathrm{C}$ for $15 \mathrm{~min}$. To start the reaction, $40 \mu \mathrm{L}$ of $2.0 \mathrm{mM}$ $\mathrm{N}$-[3-(2-furyl) acryloyl]-Leu-Gly-Pro-Ala in Tricine buffer were added, and the absorbance was continuously recorded at $345 \mathrm{~nm}$ for $20 \mathrm{~min}$.

\subsection{Binding of NA with Metal Salts}

Each iron, copper or zinc sulfate $(0-10 \mathrm{mM})$ solution was added to aqueous $5 \mathrm{mM}$ NA solution, and the solution was directly analyzed by negative ESI-MS (Tsujimoto, Hayashi, Ha, \& Kubo, 2007).

\section{Results}

\subsection{ACE Inhibition in Plant Foods}

Each plant food was extracted with 50\% aqueous ethanol solution, and the ACE inhibition activity was examined at $3.0 \mathrm{mg} / \mathrm{mL}$ (final concentration of sample). The results are summarized in Table 1. 
Table 1. ACE inihibition in plant foods

\begin{tabular}{lclc}
\hline \multicolumn{1}{c}{ Food } & $\begin{array}{c}\text { Inhibition } \\
(\%)\end{array}$ & \multicolumn{1}{c}{ Food } & $\begin{array}{c}\text { Inhibition } \\
(\%)\end{array}$ \\
\hline Asparagus stalk & 72.6 & Soybean & 85.7 \\
Avocado & 0.0 & Bamboo shoot & 26.7 \\
French bean & 0.0 & Red pepper & 34.8 \\
Turnip & 62.5 & Egg apple & 68.1 \\
Cabbage & 34.7 & Carrot & 0.0 \\
Ginkgo nut & 23.1 & Garlic & 44.7 \\
Brown rice & 0.0 & Green onion & 24.9 \\
Bitter melon & 54.6 & Broccoli & 0.0 \\
Ginger & 63.5 & Spinach & 0.0 \\
Crown daisy & 25.5 & Arternisia & 0.0 \\
Cclery & 69.7 & Peanut & 47.8 \\
Japanese radish & 3.2 & Lotus root & 0.8 \\
\hline
\end{tabular}

\subsection{Isolation and Structure Determination of an Inhibitor (nicotianamine) from Soybeans}

At first, soybeans were extracted with $50 \%$ aqueous ethanol solution. However, the ACE inhibition activity in the extract was increased when the soybeans were extracted with hot water (data not shown). The inhibitor was extracted with hot water and isolated. ${ }^{1} \mathrm{HNMR}$ of the inhibitor was indicated in Figure 2.

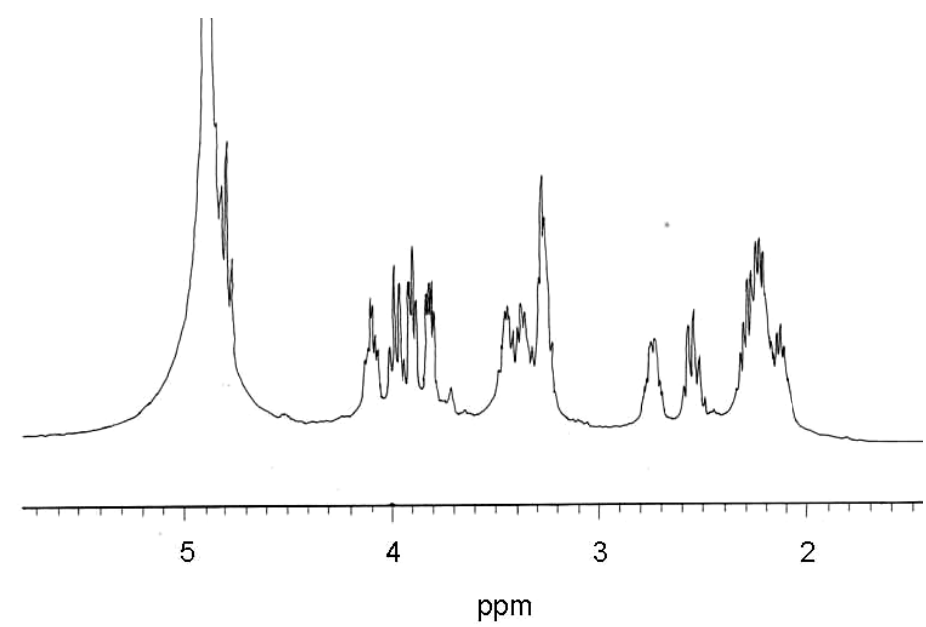

Figure 2. ${ }^{1} \mathrm{HNMR}$ spectrum of the inhibitor, NA

The signals were assigned as follows. ${ }^{1} \mathrm{HNMR}\left(\mathrm{D}_{2} \mathrm{O}\right.$, TMSP) $\delta$ 2.11-2.33 (4H, m, H-2' \& H-2'), 2.49-2.59 (1H, m, H-3), 2.73-2.75 (1H, m, H-3), 3.23-3.3.27 (2H, m, H-1" ), 3.33-3.45 (2H, m, H-1'), 3.81(1H, dd, J=8.6 \& 4.6 Hz, H-3”), 3.89 (1H, dd, J=7.2 \& 5.6 Hz, H-3'), 3.97 (1H, q, J=19.6 \& 10.0 Hz, H-4), 4.09 (1H, dd, J=7.2 \& 4.4 $\mathrm{Hz}, \mathrm{H}-4), 4.79$ (1H, t, $J=9.6 \mathrm{~Hz}, \mathrm{H}-2)$. Positive MS: $m / z 304\left(\mathrm{MH}^{+}, 100 \%\right), 286\left(\mathrm{MH}^{+}-18,37 \%\right)$. These data are consistent with the data of nicotianamine (Kristensen \& Larsen, 1974; Budesinsky et al., 1981).

\subsection{Determination of NA Content in Food}

Nicotianamine was eluted from the amino acid analyzer at $43.5 \mathrm{~min}$. (Val was eluted at $43.0 \mathrm{~min}$, and Cys at 44.0 $\min$ ). Contents in soybean products are indicated in Figure 3. The content in soybeans was highest, and, in the products, such as okara was higher than in the other foods. 


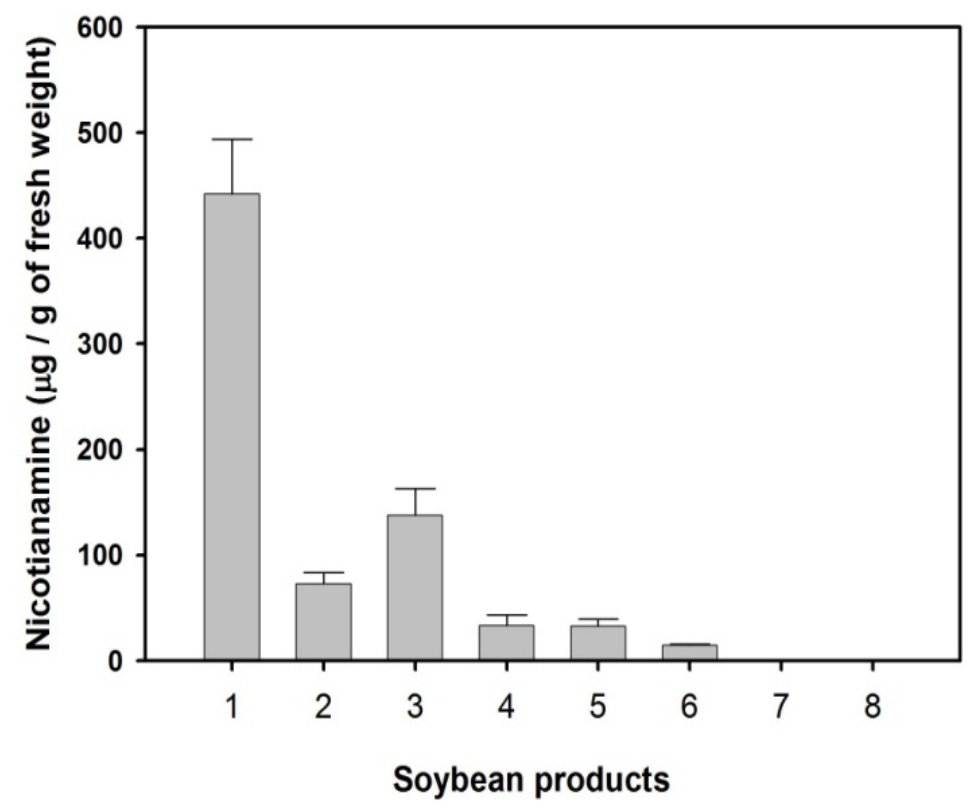

Figure 3. NA content in soybeans and the products

1: Soybeans, 2: soymilk, 3: okara (soybean curd lees), 4: kinu curd (tofu), 5: momen curd (tofu), 6: natto (fermented soybeans), 7: soy sauce (fermented), 8: soybean paste (fermented).

\subsection{Inhibition of ACE and Other Metalloenzymes with NA}

Inhibition of metalloenzymes by NA is shown in Table 2. ACE, lipoxygenase and collagenase activities were inhibited by NA.

Table 2. Inhibitory effects of nicotianamine on ACE and other metalloenzymes

\begin{tabular}{lc}
\hline Metalloenzyme & $\mathrm{IC}_{50}(\mu \mathrm{M})$ \\
\hline$\Lambda \mathrm{CE}$ & $0.99 \pm 0.05$ \\
Lipoxygenase & $5.8 \pm 1.2$ \\
Collagenase & $366 \pm 45.5$ \\
\hline
\end{tabular}

\subsection{Detection of Metal-NA Complex by Negative ESI-MS}

The binding of NA with zinc (II), ferrous (II) or ferric (III) salts was examined by ESI-MS. The MS spectrum of NA in the presence of zinc sulfate was $m / z 368(47.2 \%), 366(62.5 \%), 364\left(100 \%, \mathrm{M}-\mathrm{H}^{+}\right)$and $302(33.0 \%$, NA- $\mathrm{H}^{+}$), respectively. High resolution mass spectrum (HRMS) of the base peak (at $m / z 364$ ) was found to be 364.04991 and was assigned as $\mathrm{C}_{12} \mathrm{H}_{18} \mathrm{O}_{6} \mathrm{~N}_{3} \mathrm{Zn}$ : $\mathrm{NA}+\mathrm{Zn}-3 \mathrm{H}^{+}(364.04871$ is the calculated value as $\left.\mathrm{C}_{12} \mathrm{H}_{18} \mathrm{O}_{6} \mathrm{~N}_{3} \mathrm{Zn}\right)$. The MS spectrum in the presence of Fe (II) sulfate was $m / z 357(11.6 \%), 356\left(100 \%, \mathrm{M}-\mathrm{H}^{+}\right)$, $354(6.6 \%)$. The HRMS of the base peak was 356.05329 and was assigned as $\mathrm{C}_{12} \mathrm{H}_{18} \mathrm{O}_{6} \mathrm{~N}_{3} \mathrm{Fe}\left(\mathrm{NA}+\mathrm{Fe}-3 \mathrm{H}^{+}\right)$, (356.05450 is calculated as $\mathrm{C}_{12} \mathrm{H}_{18} \mathrm{O}_{6} \mathrm{~N}_{3} \mathrm{Fe}$ ). The MS spectrum in the presence of iron (III) sulfate was 454 $(15.0 \%), 453\left(100 \%, \mathrm{M}-\mathrm{H}^{+}\right)$. The HRMS of the base peak $(\mathrm{m} / \mathrm{z} 453)$ was 453.00703 and was assigned as $\mathrm{C}_{12} \mathrm{H}_{19} \mathrm{O}_{10} \mathrm{SN}_{3} \mathrm{Fe}$ : $\mathrm{NA}+\mathrm{FeSO}_{4}-2 \mathrm{H}^{+}$(453.01406 is the calculated value as $\mathrm{C}_{12} \mathrm{H}_{19} \mathrm{O}_{10} \mathrm{SN}_{3} \mathrm{Fe}$ ). These results demonstrate that NA and metal form a complex compound consisting of the metal and NA in a 1:1 ratio as indicated in Figure 4. 


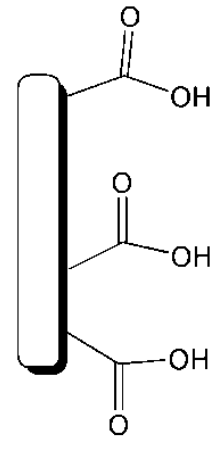

NA

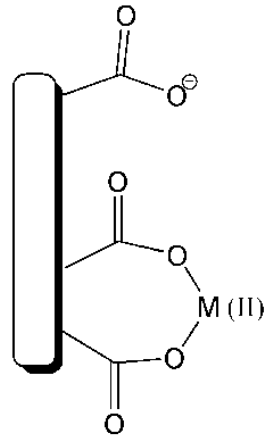

$\mathrm{NA}-\mathrm{M}-3 \mathrm{H}^{+}$

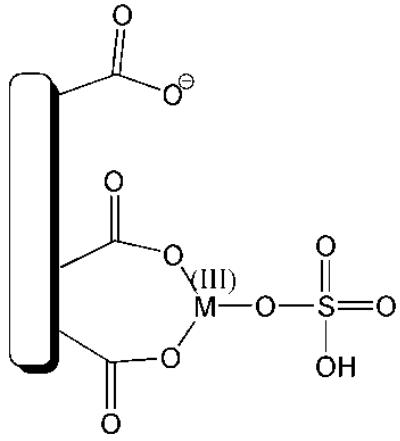

$\mathrm{NA}-\mathrm{M}-\mathrm{SO}_{4}-2 \mathrm{II}^{+}$

Figure 4. The adduct of NA-metal observed in negative EMS-MS consisted of a metal and a NA molecule (in a ratio of 1:1)

\subsection{Effect of Metal on the ACE Inhibition Activity of NA}

When $10 \mu \mathrm{M}$ (final concentration) of NA were added to the ACE assay mixture, ACE activity was perfectly inhibited (ACE inhibition $=100 \%$ ). The ACE inhibition with NA $(>95 \%)$ was kept in the presence of $80 \mu \mathrm{M} \mathrm{Fe}_{2}$ $\left(\mathrm{SO}_{4}\right)_{3}, 150 \mu \mathrm{M} \mathrm{CuSO}_{4}$ or $150 \mu \mathrm{M} \mathrm{ZnSO}_{4}$.

\section{Discussion}

ACE inhibition in plant foods was indicated in Table 1. From the high inhibitory activity and easy availability of soybeans, we chose soybeans. The active inhibitor in soybeans was extracted with hot water and was purified by using several application of column chromatography. The structure of the inhibitor was identified as NA from the NMR and MS spectra. NA is an amino acid and is soluble to water. This may be a reason why the inhibition activity in the sample extracted with hot water was higher than that extracted with ethanol solution. ACE inhibition activity of NA is considerable compared to that of captopril $\left(\mathrm{IC}_{50}=22 \mathrm{nM}\right)$ (Fujita \& Yoshikawa, 1999). NA content in soybeans and related foods was indicated in Figure 3. The content in soybeans is comparatively higher than the content in morokheiya (Corchorus olitorius) (Kimoto et al., 1998), and hayatouri (Sechium edule) (Hayashi, Nakayama, Aoyagi, \& Kimoto, 2005). The NA content in the products prepared from soybeans was also high but was reduced when soybeans were fermented. This observation might be supported by the low content of NA in soy sauce reported (Kinoshita, Yamakoshi, \& Kikuchi, 1993; Kataoka, 2005).

ACE is a metalloenzyme having a zinc atom. That is inhibited by the addition of NA or EDTA (Hayashi \& Kimoto, 2007; Williams, Corvol, \& Soubrier, 1994). NA has a chelation capacity and also specific inhibitory effects on serum and aortic ACEs. However, NA is not the inhibitor of leucine aminopeptidase and alkaline phosphatase (zinc-containing enzymes). It is still unclear whether there is NA for other metalloenzymes. Therefore, we examined the effects of NA on the activity of certain metalloenzymes (Table 2). Collagenase has a zinc atom in the active center and the zinc ligands of the active site were similar with those of ACE (Soubrier et al., 1988), while lipoxygenase has a ferrous or ferric atom, non-heme, in the active site (Meyer, Tomchick \& Klinman, 2008). Both collagenase and lipoxygenase were inhibited by addition of NA. As it was reported that the $\mathrm{IC}_{50}$ value of anacardic acid for lipoxygenase was $6.8 \mu \mathrm{M}$ (Tsujimoto et al., 2007) and that of EDTA for collagenase was $580 \mu \mathrm{M}$ (Barla et al., 2009), we deduced that inhibitory activity of NA was in part associated with its chelation capacity. The complex formations of NA with metals were examined by using negative ESI-MS. In the ESI-MS of NA in the presence of zinc sulfate, Fe(II) sulfate, and Fe(III) sulfate, respectively, the base peaks indicated that NA formed chelation adducts with all of these metals, and that these adducts consisted of a metal and a NA molecule (in a ratio of 1:1) as shown in Figure 4. Therefore, NA inhibits the enzymatic activity when it is able to bind the metal in the active site of metalloenzymes. On the other hand, it is suggested that the ACE inhibition activity by NA is suppressed with metal content in the media. ACE inhibition activity with NA was examined in the presence of metals. The result suggests that metal content in blood under normal blood conditions (Ohno \& Sakai, 1997) does not affect ACE inhibition, and it is deduced that NA effectively lowers blood pressure when NA in foods is absorbed. Further studies are underway. 


\section{References}

Barla, F., Higashijima, H., Funai, S., Sugimoto, K., Harada, N., Yamaji, R., ... Inui, H. (2009). Inhibitive effects of alkyl gallates on hyaluronidase and collagenase, Biosci. Biotechnol. Biochem., 73, 2335-2337. http://dx.doi.org/10.1271/bbb.90365

Budesinsky, M., Prochazka, Z., Budzikiewicz, H., Romer, A., Ripperger, H., Schreiber, K. \& Scholz, G. (1981). On the "normalizing factor" for the tomato mutant "chloronerva"-XI. Tetrahedron, 37, 191-196.

Cushman, D. W., \& Cheung, H. S. (1971). Spectrophotometric assay and properties of the angiotensin-converting enzyme of rabbit lung. Biochem. Pharmacol., 20, 1637-1648. http://dx.doi.org/10.1016/0006-2952(71)90292-9

Fujita, H., \& Yoshikawa, M. (1999). LKPNM: a prodrug-type ACE-inhibitory peptide derived from fish protein. Immunopharmacology, 44, 123-127. http://dx.doi.org/10.1016/S0162-3109(99)00118-6

Guerrero, L., Castillo, J., Quinones, M., Garcia-Vallve, S., Arola, L., Pujadas, G., \& Muguerza, B. (2012). Inhibition of angiotensin-converting enzyme activity by flavonoids: Structure-activity relationship studies. Plos One, 7(11), e49493.

Hayashi, A., \& Kimoto, K. (2007). Nicotianamine preferentially inhibits Angiotensin I-converting enzyme. $J$. Nutr. Sci. Vitaminol, 53, 331-336. http://dx.doi.org/10.3177/jnsv.53.331

Hayashi, A., Nakayama, T., Aoyagi, Y., \& Kimoto, K. (2005). Purification of Nicotianamine from Hayatouri (Sechium Edule) and Estimation of Quantitative Determination Method. Nippon Shokuhin Kagaku Kogaku Kaishi, 52(4), 154-159. http://dx.doi.org/10.3136/nskkk.52.154

Kataoka, S. (2005). Functional effects of Japanese style fermented soy sauce (shoyu) and its components. Journal of Bioscience and bioengineering, 100(3), 227-234. http://dx.doi.org/10.1263/jbb.100.227

Kimoto, K., Kuroda, Y., Saito, Y., Yamamoto, J., Murakami, T., \& Aoyagi, Y. (1998). Purification and Identification of angiotensin I-converting enzyme inhibitory from morokheiya (Corchorus olitorius). Food Sci. Technol. Int. Tokyo, 4(3), 223-226. http://dx.doi.org/10.3136/fsti9596t9798.4.223

Kinoshita, E., Yamakoshi, J., \& Kikuchi, M. (1993). Purification and identification of an angiotensin I-converting enzyme inhibitor from soy sauce. Biosci. Biotech. Biochem., 57(7), 1107-1110. http://dx.doi.org/10.1271/bbb.57.1107

Kristensen, I., \& Larsen, P. O. (1974). Azetidine-2-carboxylic acid derivatives from seeds of fagus silvatica L. and revised structure for nicotianamine. Phytochemistry, 13, 2791-2798. http://dx.doi.org/10.1016/0031-9422(74)80243-8

Meyer, M. P., Tomchick, D. R., \& Klinman, J. P. (2008). Enzyme structure and dynamics affect hydrogen tunneling: The impact of a remote side chain (I553) in soybean lipoxygenase-1. Pro. Natl. Acad. Sci. USA, 105(4), 1146-1151. http://dx.doi.org/10.1073/pnas.0710643105

Ohno, N., \& Sakai, T. (1997). Spectrophotometric determination of iron, copper and zinc in sera using 2-(5-nitro-2-pyridylazo)-5-( $N$-propyl- $N$-sulfopropylamino)phenol. Bunseki Kagaku, 46, 937-942. http://dx.doi.org/10.2116/bunsekikagaku.46.937

Rickert, K. W., \& Klinman, J. P. (1999). Nature of hydrogen transferin soybean lipoxygenase-I: separation of primary and secondary isotope effects. Biochemistry, 38, 12218-12228. http://dx.doi.org/10.1021/bi990834y

Soubrier, F., Alhenc-Gelas, F., Hubert, C., Allegrini, J., John, M., Tregear, G., \& Corvol, P. (1988). Two putative active centers in human angiotensin I-converting enzyme revealed by molecular cloning. Proc. Natl. Acad. Sci. USA, 85, 9386-9390.

Takahashi, M., Terada, Y., Nakai, I., Nakanishim, H., Yoshimura, R., Mori, S., \& Nishizawa, N. K. (2003). Role of nicotianamine in the intracellular delivery of metals and plant reproductive development. The Plant Cell, 15, 1263-1280. http://dx.doi.org/10.1105/tpc.010256

Thring, T. S. A., Hili, P., \& Naughton, D. P. (2009). Anti-collagenase, anti-elastase and anti-oxidant activities of extracts 21 plants. BMC Complementary and Alternative Medicine, 9, 27. http://dx.doi.org/10.1186/1472-6882-9-27

Tsujimoto, K., Hayashi, A., Ha, T. J., \& Kubo, I. (2007). Anacardic acids and ferric ion chelation. Z. Naturforsch., 62c, 710-716.

Williams, T. A., Corvol, P., \& Soubrier, F. (1994). Identification of two active site residues in human angiotensin I-converting enzyme. J. Biol. Chem., 269, 29430-29434. 